\title{
Leitura e livros para bebês e crianças até 5 anos de idade: análise e sistematização da produção acadêmica
}

\author{
Giovana Roldão da Silva*, Cláudia B. de C. N. Ometto.
}

\begin{abstract}
Resumo
Assumindo que a constituição do sujeito, mediada pela leitura, inicia desde os primeiros meses de vida, o objetivo central da presente iniciação científica é realizar, através de revisão bibliográfica, um levantamento das dissertações e teses disponíveis no Banco de Teses da Coordenação de Aperfeiçoamento de Pessoal de Nível Superior (CAPES) 2008-2018 - que tenham como objeto de estudo práticas de leitura desenvolvidas por/com bebês e crianças até 5 anos de idade, em espaços educativos formais, para sistematizar experiências documentadas sobre a leitura praticada/possibilitada para bebês e crianças até 5 anos de idade.
\end{abstract}

Palavras-chave: Leitura. Formação do leitor. Trabalho com a linguagem.

\section{Introdução}

Este projeto está vinculado à linha de pesquisa "Linguagem e Arte em Educação", do Grupo Alfabetização, Leitura, Escrita e Trabalho Docente na Formação de Professores - ALLE/AULA, cadastrado no Diretório dos Grupos de Pesquisa do $\mathrm{CNPq}$ e, mais especificamente, a um projeto aprovado na Chamada Universal MCTI/CNPq № 01/2016 (Processo no 401404/2016-1), que busca compreender como a formação dos professores das salas de leitura vai se consolidando e, ao mesmo tempo, compreender aspectos relativos à formação de leitores na escola básica. No entanto, compreendemos que a leitura, mais especificamente a leitura da literatura, para bebês e crianças até 5 anos, é fundamental no processo de constituição da subjetividade humana e de formação do leitor.

\section{O referencial teórico-metodológico que} assumimos na pesquisa: as referências teóricas de Vigotski (1989), para o qual a linguagem é constitutiva do pensamento, portanto, do desenvolvimento humano; a teoria enunciativo-discursiva de Bakthin (2002), para o qual a linguagem é constitutiva dos sujeitos que vivem em relações sociais - mediadas pela linguagem.

Realizamos a busca na página da Biblioteca Digital Brasileira de Teses e Dissertações - BDTD do Instituto Brasileiro de Informação em Ciência e Tecnologia - IBCT, pelas palavras chave relacionadas ao nosso foco de pesquisa como: leitura, bebês, literatura, criança pequena, livros, entre outras.

\section{Resultados e Discussão}

Segundo nossos estudos, entendemos que desde que nasce a criança é um sujeito social, quando bebê, já interage com gestos, olhares, sons, depois vai desenvolvendo sua fala, linguagens, e segundo Vigotsky (1991), o ser humano é personalidade social e a partir de sua interação com o meio social. Nesse sentido, as funções psicológicas são construídas e constituídas pela estrutura social.

Nessa direção assumimos a linguagem como uma forma de interação humana referência assumida por Vigotsky (1989), em que o sujeito que fala não apenas transmite informações ao receptor, mas constitui vínculos, compromissos, sentimentos com o ouvinte.

Em nossa pesquisa, encontramos 5.531 artigos, porém destes, 57 contemplavam os objetivos de nossos estudos. Após uma leitura criteriosa, selecionamos 15 trabalhos com estudos que abordassem leitura e práticas literárias para bebês e crianças de educação infantil, produção de livros literários para educação infantil, mediação da leitura por professores de crianças pequenas, mediação em espações literários, cultura de uso do objeto livro para bebês e desenvolvimento da cultura letrada, interação de bebês e crianças pequenas com livros literários, prática pedagógica, entre outros.

\section{Conclusões}

A partir da leitura do material encontrado é possível afirmar que a literatura proporciona 0 desenvolvimento do pensamento, da imaginação e da fantasia, e para as crianças, "a imaginação é um momento totalmente necessário, inseparável do momento realista" (VIGOTSKY, 1992, p.128), além de proporcionar que cada sujeito relacione a história às suas próprias vivências, ou pela imaginação e fantasia, pode assumir papéis de personagens do texto, refletindo acerca das condições psíquicas, emocionais e sociais que está sendo vivenciado no momento.

Através de nossos estudos, entendemos que "a criança desde seu nascimento vive em um mundo de palavras do outro. As palavras do outro fazem parte de sua formação como ser expressivo e falante que a criança é" (ESCOUTO, 2013, p.128). E a leitura de literatura nas escolas, como um momento planejado e pensado, se dá pela interação, troca de conhecimentos, promovendo enriquecimento do vocabulário, desenvolvimento de diferentes linguagens, para que a criança se reconheça no mundo letrado e em sua cultura.

BAKHTIN, M. Marxismo e filosofia da linguagem. São Paulo: Hucitec, 2002.

VIGOTSKI, Lev Semenovich. A formação social da mente: o desenvolvimento dos processos psicológicos superiores. 7. ed. São Paulo: Martins Fontes, 1989.

ESCOUTO, Nivia Barros. A formação do leitor-literário na educação infantil: a interação da palavra da vida cotidiana com a palavra literária. 2013. 196p. Dissertação (mestrado) - Universidade Federal de Santa Catarina, Centro de Ciências da Educação, Programa de Pós-Graduação em Educação, Florianópolis, 2013. Disponível em:

https://repositorio.ufsc.br/xmlui/handle/123456789/122715 